\title{
DA CARNAVALIZAÇÃO DO PLANEJAMENTO URBANO PARA BELO HORIZONTE-PARA-A-GUERRA: \\ DA POLÍTICA AO POLÍTICO E VICE-VERSA ${ }^{1}$
}

\author{
FROM THE CARNAVALIZATION OF URBAN PLANNING \\ TO BELO HORIZONTE-FOR-WAR:
}

FROM POLITICS TO THE POLITICAL AND VICE VERSA

\author{
Frederico Canuto \\ Universidade Federal de Minas Gerais, Escola de Arquitetura, Belo Horizonte, MG, Brasil
}

\begin{abstract}
R E S U M O : O presente trabalho tem como objetivo discutir o conceito festa como campo de produção de novas formas de viver na cidade, dando ao carnaval de Belo Horizonte especial atenção e tomando como recorte temporal seu chamado renascimento em 2009, sua capilaridade frente ao Estado como fonte de estratégias de luta pelo direito à cidade e de fomento de políticas públicas e iniciativas de planejamento urbano. O argumento do texto é de que o paradoxo democrático (Chantal Mouffe) em produção na festa transforma a cidade de Belo Horizonte em uma espacialidade de guerra - não uma guerra que reproduz exercícios de poder, mas que contamina e produz novas multiplicidades.
\end{abstract}

P A L A V R A S - C H A V E : planejamento urbano; festa; democracia; política; carnaval; guerra.

A B S T R A C T : The present paper aims to discuss the concept of festa as a concept field for producing new modes and forms of living within cities. In order to depict the strategies of festa, it will be use as an example the carnival in Belo Horizonte, a city in the southeastern region of Brazil. Since the city's carnival revival in 2009, it has been appropriated by the state as a source of strategies both struggling to reclaim the right of the city andlor for the development of public politics and urban planning initiatives. The argument herein is that the democratic paradox (Chantal Mouffe) brought about through the festa transforms the city into a spatiality of a war, although not a war that serves to reproduce the exercise of power of the state, but rather one that contaminates and produces diversity.

K E Y W O R D S : urban planning; festa; democracy; politics; carnival; war.

DOI: https://doi.org/10.22296/2317-1529.2016v18n3p485

1 Este trabalho faz parte da pesquisa "Urbanismo de Guerra: Narrativas de 2013", financiado pelo CNPq, por meio do edital $\mathrm{MCTI} / \mathrm{CNPq}$ /Universal 14/2014. O autor gostaria de agradecer a Juliana Rocha Franco, Paola Ferrari, Marion Kato, Luiza Barbosa e Aline Maracahipe, com quem venho desenvolvendo este trabalho. 


\section{PREÂMBULO}

No contexto brasileiro, desde 1970, o carnaval é visto e vivido como um evento popular aprazível e propagandeado através de imagens reproduzidas pela mídia durante os dias da festa carnavalesca. Reduzido a blocos e desfiles de escola de samba nas ruas, salóes e espaços reservados, o carnaval foi desvinculado de seu potencial histórico de abertura e imaginação de novos modos de vida, haja vista sua dimensão festiva, contraventora e espacial. No entanto, nas duas primeiras décadas dos anos 2000, em Belo Horizonte e cidades como São Paulo e Brasília, o carnaval retomou sua dimensão política, chegando inclusive a contaminar o próprio Estado com tal alegria carnavalesca. A partir da formulaçấo de políticas públicas que incorporam a dimensão fantasiosa da festa e de açóes de planejamento urbano que trazem para dentro das prefeituras iniciativas advindas desse evento popular, pequenos espaços democráticos vão se formando de dentro para fora, e vice-versa.

O presente trabalho parte de uma pesquisa denominada "Urbanismo de Guerra", cujo objetivo é pensar os modos como a população se organiza socioespacialmente para entrar em embate contra o Estado, associado ao capital privado, a fim de reivindicar e inventar/multiplicar novas formas de fazer política, inclusive contaminando-os. Neste artigo, o objetivo é abordar uma estratégia específica de guerra no espaço urbano: o carnaval. Inicialmente, será discutido tal evento como festa, abordando sua dimensão política e democrática. Num segundo momento, será abordado o carnaval como uma festa espetacularmente brasileira; depois, haverá uma contextualização do chamado renascimento do Carnaval de Belo Horizonte em 2009. O intuito é pensar e discutir o carnaval, por meio de seus desdobramentos sensíveis e afetivos, como uma ontologia, fundamentado no conceito de guerra proveniente das sociedades ameríndias, uma guerra que se baseia num movimento socioespacial que se apoia não na dominação de um sobre outro, mas na multiplicação de outros.

2 Em A Revolução Urbana, Henri Lefebvre (2000, p. 9-17), de maneira simplificada, mas nem por isso menos complexa, aponta a cidade industrial que emerge no século XIX como um reflexo e propulsor da mudança de centralidade da vida coletiva do campo para a cidade.

3 A trilogia, composta de cursos apresentados no College de France, é a seguinte: Em Defesa da Sociedade (2005), Segurança, Território e População (2008a) e O Nascimento da Biopolítica (2008b).

\section{DA FESTA AO CARNAVAL}

Na Modernidade, o embate entre diversos modos de pensar e produzir a vida se dá segundo uma configuração que se pauta em três elementos: primeiramente, na cidade - espaço que, conforme o filósofo francês Henri Lefebvre (2000), ganha centralidade na vida das pessoas na Modernidade, especialmente a partir da revolução industrial no século $\mathrm{XIX}^{2}$; depois, nas formas de organização e gestão da vida vivida em função do binômio Estado Nacional e Mercado, tendo em vista que o Estado monárquico dá lugar a uma configuração imposta de origem nacionalista, soberana e democrática, na qual diferenças afloram e são governamentalizadas, de acordo com Michel Foucault em sua trilogia a respeito dos modos de exercício do poder $^{3}$; e, por último, em uma tendência econômico-política de exercício de poder que precariza e normaliza a vida baseando-se numa lógica capitalizadora de corpos e afetos. Nesse contexto, o festejar, o dançar e o celebrar se apresentam como oportunidades políticas em que tal modo de vida citadino, fundado numa produtividade chancelada pelo Estado e na lucratividade, dada sua associação com o capitalismo, é passível de superação ou transformação. 
De estudos antropológicos e históricos a teorias filosóficas, a festa na Modernidade não é apenas uma reproduçáo do status quo, mas também uma imagem ou amostragem do que outros mundos podem vir a ser, segundo outras epistemologias, não as calcadas num funcionalismo e produtivismo esvaziado de um sentido não mercadológico, como a condição moderna aponta. A festa, assim, aparece como uma operação propositiva e transformadora, de criação, de produção de subjetividades coletivas. Em Dançando nas Ruas, a ensaísta Barbara Ehrenreich (2010) faz uma discussão histórica e antropológica de como a festa, no contexto dos chamados povos primitivos e mesmo da civilização antiga grega, aponta para a produçáo de novas formas políticas e de sociabilidade. A partir de relatos históricos do encontro dos homens brancos com negros e indígenas e do estranhamento/familiaridade dos primeiros no que diz respeito aos rituais e festividades dos segundos, assim como de leituras sociológicas e etnográficas sobre o modo como coletividades são construídas socialmente, essa autora demonstra como a festa desses povos tem um forte componente político. A festa como evento popular e irrestrito (isto é, não restrito a um "público de iguais" como o atual carnaval de camarotes e áreas vips) tinha como efeito a anulação de determinadas organizações hierárquicas sociais, limitaçóes e comportamentos grupais - todos suspensos pela dança e pela música ${ }^{4}$. Novas identidades e formas de experimentar a cidade eram produzidas por meio das fantasias e das brincadeiras, como os rituais de inversão $0^{5}$; novos sentimentos de pertencimento e coletividades ${ }^{6}$ eram inventados. Como diz a autora, tal politização da festa chegou a ser tấo perigosa a ponto de, a partir do Império Romano e do nascimento e explosão do cristianismo por toda a Europa, tal maneira de festejar ter sido redirecionada como festa para reforçar identidades cristãs ou imperiais, e não para produzir novos laços coletivos pelo amor, afeto ou amizade.

O professor da Universidade de São Paulo Norberto Luiz Guarinello (2001), em Festa, Trabalho e Cotidiano, sustenta a necessidade de pensar a festa na contemporaneidade como parte da vida das pessoas e como uma forma de produção de identidades, cambiantes e contingentes, como evento que tem uma lógica econômico-política própria, com contornos sociais performáticos e que produzem rupturas na rotina cotidiana.

O grupo sessentista Situacionista ${ }^{7}$, por sua vez, tinha esse questionamento da vinculação entre festa e imaginação/experimentação política tão claro que criou uma teoria de ação festiva e remodeladora do mundo, a começar pelo homem e o espaço da cidade: a Situação. Segundo um dos principais expoentes do grupo, o francês Guy Debord, tal teoria, num contexto citadino, baseia-se na criação de situaçôes - eventos criados e planejados para escapar de uma vida dócil, de comportamentos e gestos regrados - para, assim, construir outra vida, a partir de individuaçóes, na qual desejos e pulsóes individuais apareceriam como catalisadores de singularidades e novos modos de apropriar e reinventar a cidade, produzindo "[...] um campo de atividade temporária favorável a esses desejos" (DEBORD, 2003, p.62). A Situação era uma festa com objetivos políticos revolucionários bem específicos, a ponto de ter um programa cujos principais alvos de análise e crítica eram o urbanismo, o planejamento urbano e, em especial, a mobilidade urbana. Em Questôes Preliminares para a Construção de uma Situaçấo, de 1958, por exemplo, o autor francês deixa claro essa crítica ao destacar a limitação funcionalista da época e a necessidade de transformar a realidade das cidades de forma coletiva.
4 Sobre a importância da dança como resposta ao chamado de Dionísio na Grécia Antiga, a autora afirma: "Dionísio tinha um apelo especial para as mulheres das cidades-estado gregas, que em geral viviam numa condição parecida com a purdah, excuídas da vida comunal de qualquer tipo. [...] A forma mais notória de adoração de Dionísio era a dança do inverno, oreibasia, que parece aos olhos modernos uma imitação grosseira das revoltas feministas. Em relatos míticos, mulheres chamadas a participar pelo deus perdem o juízo e abandonam suas crianças para correr ao ar livre rumo às montanhas, onde vestem peles de corço e iniciam uma dança frenética" (EHRENREICH, 2010, p. 49-50).

5 "Na reencenação da caça comunal pré-histórica, seus adoradores ousavam subverter a divisão de tarefas entre os sexos que prevalecia desde os tempos históricos [...]. Durante as festas, os mestres tinham de servir seus escravos; o carnaval permitia que camponeses personificassem reis, a adoração a Dionísio dava às mulheres licença para caçar" (EHRENREICH, 2010, p. 53).

6 "Na realidade, os rituais e festividades sazonais provavelmente serviam a uma função reprodutiva, proporcionando uma possibilidade de encontrar um parceiro exterior ao círculo de parentesco de cada um [...]. Ao menos essa possibilidade é sugerida a partir de um recente estudo com homens jovens e solteiros entre os samburu, no Quênia" (EHRENREICH, 2010, p. 41).

7 Grupo de artistas que surgiu nos anos 1950, cujo objetivo era fazer uma arte que se misturasse à vida, provocando e produzindo novas modalidades de uso e ocupação do espaço a partir de derivas, construção de situações e crítica ao urbanismo modernista. 
Assim, nos contextos em que a festa aparece como um evento político pela politização da vida cotidiana para sua possível transformação, pensar a dimensão política torna-se central. Tomando as asserçôes da cientista política belga Chantal Mouffe a respeito da democracia e da política em uma entrevista com Ińigo Errejon, observa-se que é pelo fazer político e pela política que se fundam as bases para a criação de novos povos, novas linguagens, novas formas de agir. A fala de Errejon enfatiza o momento em que oportunidades e situaçôes estavam sendo criadas pelo povo espanhol após as perdas causadas pela crise financeira de 2008: coletivos transformaram-se em forças partidárias que puseram em xeque a institucionalidade política, por exemplo, ganhando as eleiçôes municipais e até mesmo as nacionais com o aval de uma base popular multitudinária. Assim, como ambos os autores mostram, no político, entendido como conflito entre interessados, e na política, compreendida como negociação e representação desses mesmos atores sociais interessados (MOUFFE; ERREJON, 2015), novas situações são criadas e novas oportunidades emancipatórias tornam-se possíveis com a instauração de novas formas de viver na cidade.

Continuando com Mouffe (2000), para o exercício transformador da política e do político, é preciso sair do modelo adversarial que sempre pautou o jogo político para um modelo agonístico, no qual, segundo a autora, todos reconheceriam os lugares de fala como legítimos; além disso, é necessário partir para a construção de novas bases, inclusive epistemológicas, para discutir questóes comuns (MOUFFE, 2000). Assim, não se trata de ganhar ou perder, mas de construir afetos entre os diversos adversários em torno de uma questáo comum; não se trata de eleger uma possibilidade como a verdadeira, mas de construir pactos, ainda que temporários, sobre bases muito específicas.

O mais interessante é que a cientista política belga discute o caráter paradoxal da política a partir dessa proposta agonística ao percebê-lo no modelo democrático atual: a necessidade de formas de democracia e tomada de decisão mais diretas e, ao mesmo tempo, de representação, como meio de resguardo de questôes que dizem respeito a grupos minoritários. Paradoxal, palavra que aponta para uma contradição que permite coexistência, e isso é a democracia: de um lado, direta, porque não se pauta em mediadores e caracteriza-se pelo agir concreto e direto no espaço, e, por outro, com poderes organizados nas mais diversas representaçôes políticas e que se influenciam mutuamente, direcionando a tomada de decisóes do Estado pelo agir em campo, cada qual com seu poder de barganha e influência. É para tais questôes que a festa na Modernidade aponta como paradoxo: uma ação direta no espaço, produzida pelo desejo de visibilizar, criar, produzir e performatizar novas formas de representaçáo de

8 Giorgio Agamben é tradutor das obras de Walter Benjamin para o italiano.

9 É sabida a dívida que Agamben tem com Michel Foucault, tendo em vista que sua obra política fundamental, Hommo Saccer, cujo objeto são as relações entre linguagem, política e direito na produção de um contexto biopolítico, tem como uma de suas bases conceituais a obra do filósofo francês. grupos minoritários ou até mesmo daqueles que escapam de qualquer nomeação pelo seu caráter nu: o povo.

Aqui se pensa a noção de povo da perspectiva agambeniana, que, por sua vez, advém de leituras de Walter Benjamin ${ }^{8}$ e Michel Foucault ${ }^{9}$, tendo em vista tal nomeação conceitual como uma determinação, inclusive jurídica, que fala de um tipo específico de vida. Para o filósofo italiano, a nomeação povo é sustentada como uma nomeação exemplar que oferece um valor peculiar aos homens, conclusão a que chega usando, em seu caso de análise, a situação judia na Alemanha nazista como etnia que deveria não existir: 
[...] poderíamos dizer que a biopolítica moderna é sustentada pelo princípio segundo o qual "onde há vida nua, o povo deverá ser"; sob a condição porém de acrescentar imediatamente que tal princípio vale também para a formulação inversa, que quer que "onde há um povo, ali haverá vida nua" [...]. E de modo diferente mas análogo, hoje o projeto democrático-capitalista de eliminar, através do desenvolvimento, as classes pobres não só reproduz no seu interior o povo dos excluídos, mas transforma em vida nua [...] (AGAMBEN, 2015a, p. 39-40).

A vida nua, aquela não reconhecida pelo Estado e, portanto, sem direito, a não ser apenas de existência, que não está à margem mas sim fora de qualquer possibilidade, inclusive limiar, é aí que o povo se instala, e é para ele que a festa também existe - não para nomeá-lo, mas para permitir sua performatização em identidades múltiplas, contingentes e frágeis. Uma festa para, num gesto hospitaleiro radical, trazê-los à existência e criar novas formas comunitárias de resistência contra a anulação de sua própria vida como humana.

A festa, como política paradoxal - produto da associação de ação direta e da produção de representaçóes - é uma potente imagem não para ser estetizada e, por conseguinte, controlada. É dispositivo que politiza o mundo e suas imagens, se compreendida a partir da questão da relação entre imagem e estética exposta por Walter Benjamin (1985) em Obra de Arte na Era de sua Reprodutibilidade Técnica, quando o autor analisa os afetos entre imagem, politização e estetizaçáo no contexto da guerra. Considerando a guerra não como um evento excepcional, mas como uma palavra que caracteriza o embate pelas e nas ruas da cidade hoje, com suas políticas de eugenia e suas origens fascistas de limpeza da diferença, a politização das imagens festivas é uma direção para um projeto que pensa a si mesmo como democrático. Se for tomada a disputa pelo espaço entre a reprodução de relações de produção socioespaciais capitalistas, tal como é feito em Lefebvre (1976), e as novas e renovadas formas de produção da vida como uma guerra silenciosa ocorrendo na cidade, a festa se coloca como momento fulcral do embate. Se o comum é sempre estetizar a festa a partir da reprodução de imagens fáceis, produzidas e replicadas em contextos vários, quando usada como arma para mudança, ela politiza tudo, inclusive a vida. Fazendo um paralelo com Benjamin (1985, p. 195), pode-se dizer que se "[t]odos os esforços para estetizar a política convergem para um ponto. Esse ponto é a guerra. A guerra, e somente a guerra, permite dar um objetivo aos grandes movimentos de massa, preservando as relaçôes de produção existentes". Entretanto, inversamente, usar as imagens da festa como instrumentos de transformação significa, em resposta ao facismo estetizador, politizar a vida (BENJAMIN, 1985, p. 196).

No contexto brasileiro, uma das materializaçôes dessa festa é o carnaval. Este não é apenas uma festa que celebra a si mesma durante cinco dias, resumindo-se em música, dança e corpos à mostra, como propagandeado pela televisão, que estetiza seus elementos ao apresentá-los como discurso unificador e unificado. Se o carnaval for considerado em sua dimensão política e em sua relação com o espaço, com o Estado e com o consequente controle biopolítico populacional, percebe-se que ele atravessa a ordem hegemônica, sendo uma política que produz uma imagem de superação, quando não de transformação: uma imagem politizada que provoca açóes e representações.

A Modernidade, apresentada como promessa de progresso, trouxe para a vida 
cotidiana uma repetição infindável de conflitos. Dado tal recorte, é imprescindível pensar o carnaval como um jogo democrático em que o que está posto é uma relação agonística entre carnavalescos, poderes público, privado e suas respectivas associaçôes. Um jogo entre estetização do cotidiano e politização da vida dentro de uma democracia que é paradoxal por princípio. E o carnaval em Belo Horizonte é uma repetição desses embates, mas com idiossincrasias, sendo sintoma de um contexto no qual as ideias de ordem e homogeneização se impóem a uma diversidade plural e desejosa. Mais ainda, ele aparece como um evento tático que se coloca como oposição, contaminando a vida com outras possibilidades de ordem, como será visto adiante.

O carnaval de Belo Horizonte se apresenta, pois, como um processo festivo, intensificado na relação entre cidade, Estado e lógica de capitalização, que produz e reproduz um embate nas ruas entre polícia, carnavalescos, blocos de rua, empresas, Poder Público e afetos, a partir de uma perspectiva centrada no corpo individual e coletivo e na capacidade democrática paradoxal: agir diretamente sobre o espaço e criar representaçóes para minorias e para o povo. Tal emaranhado complexo de disputa pelos sentidos e formas de carnaval será discutido, neste artigo, usando o conceito de microscópio, no sentido explorado por Haesbaert (2014, p.162) em sua releitura do termo advindo de Deleuze e Foucault:

[...] micro, de microfísica, afirma Deleuze, deve ser visto como [...] um outro domínio, um novo tipo de relaçôes, uma dimensão de pensamento irredutível ao saber, ligaçôes móveis e não localizáveis. Dito de outra forma, acrescenta o próprio Foucault, "a análise dos micropoderes (ou dos procedimentos de governamentalidade) não é uma questão de escala, não é uma questão de setor, é questão de ponto de vista, uma razão de método.

\section{MÍdIAS E MEDIAÇÕES}

O espetáculo, segundo Guy Debord (1997), em Sociedade do espetáculo, é relacionado comumente ao teatro ou, ainda, a imagens produzidas pela mídia. Mas o mais radical e potente sentido da palavra - e criado pelo autor francês - é, necessariamente, aquele que remete ao contexto biopolítico - isto é, biológico, físico, social e somático - em que ela age e perpetua-se como verdade que revela a si mesma como vazio de significação.

O carnaval está longe de ser o evento construído pela mídia como festa popular tipicamente brasileira, desdobrando-se, assim, no espetáculo debordiano. Fantasias de milhares de reais (ROUVENAT, 2016), corpos sarados e barrigas talhadas nas academias para desfilar na passarela do samba (MOLIARI, 2016); pessoas brancas, pulando e festejando com cerveja nas mãos ao som de cantores como Cláudia Leite e Ivete Sangalo, sem qualquer intervenção militar; centros da cidade bem pavimentados e devidamente cuidados como palco central da festa: essas são as imagens que televisóes, jornais e redes sociais reproduzem ad infinitum. O teatro montado, em que os atores - os foliôes, os repórteres e as pessoas - estão sempre felizes num palco - a cidade - onde tudo ocorre, sem que haja qualquer tipo de ocorrência que coloque em questão tal imagem pacificadora, é a imagem resumo. Nessas sintéticas paisagens imagéticas, há uma estetização do mundo que se repete nas relaçóes, mediadas pelo espetáculo num nível microscópico. Como expõe o sociólogo Jessé de Souza (2015) 
em seu brilhante $A$ tolice da inteligência brasileira, tal paisagem midiatizada reforça a ideia e a imagem de uma identidade brasileira e do que é o Brasil, ambas sustentadas em pensadores brasileiros que a produziram sem uma pesquisa qualitativa rigorosa, na verdade, baseada em um precário conhecimento empírico personalista. Seguindo uma extensa análise da produçáo desses autores, de Sergio Buarque de Holanda e Gilberto Freyre a Raymundo Faoro, para Souza (2015), o Brasil é produzido, na academia e reproduzido discursivamente pelo senso comum das ruas, como um país da cordialidade (confundida com aceitação), da passividade, da festa, portanto, do não trabalho, das cores e da diversidade étnica, dos corpos sexualizados, aspecto que remete, por sua vez, a uma falta de inteligência mental, tal qual os norte-americanos - exemplo de nação a ser seguida no imaginário brasileiro.

Essa imagem de Brasil, esmiuçada por Jessé de Souza por meio de uma arqueologia da maneira pela qual a inteligência brasileira a construiu, expondo correntes de pensamento próximas e métodos de pesquisa, é vendida a europeus e norte-americanos como um imaginário do exótico, da não racionalidade, do gosto pelo ócio despretensioso; vendida, principalmente, ao próprio país como seu reflexo, que deve ser cotidiana e continuamente reproduzido num nível micro. Não importa se estudos mostrem o contrário - ou seja, o Brasil como lugar de uma inteligência e racionalidade particulares, em pé de igualdade com países do norte global ou mesmo trabalhador, como demonstra a antropóloga Elisete Zanlorenzi, que dissocia a imagem preconceituosa que atrela baianos à preguiça, demonstrando, em conclusão, que o baiano é justamente o contrário -, a imagem substitui a realidade.

E é nessa disputa de saberes e discursos que a mídia acaba por mediar relaçóes internas à própria sociedade, ou, nas palavras de Guy Debord (1997, p. 16), é nela que "[o] espetáculo [deixa de ser] um conjunto de imagens, [e se torna] relaçóes sociais mediadas por imagens”. A biopolítica, compreendida por Foucault (2005, p. 3) como um "[...] conjunto de mecanismos pelos quais aquilo que, na espécie humana, constitui suas características biológicas [torna-se] uma política, uma estratégia política, uma estratégia geral de exercício de poder", é o que surge ou dá apoio a tal espetáculo, associando-se como política veiculada não a um disciplinamento da populaçáo, mas sim ao controle dela por meios e subterfúgios menos invasivos e mais interessados no asseguramento - etimologicamente, palavra que vem de segurança - de um estado de coisas. O carnaval, midiatizado e televisionado, acaba por reforçar - somar esforços, vindos do Estado e entrelaçados com o mercado - uma paralisia do desejo, transformando-o em mercadoria de consumo despolitizado.

No espaço socialmente vivido e (re)produzido nas cidades através da introjeçáo de gestos e organização dos corpos pelo Estado e pelo mercado, os quais são replicados pela população, a disposição do modo como o carnaval acontece territorialmente não é aleatória. O que cada vez mais se pretende é reproduzir um estado contínuo de segregação e periferizaçâo da cidade, como se pode ver, por exemplo, na lógica da camarotização em voga em muitos dos carnavais do Nordeste e Sudeste do país (MENDES, 2016). O espaço próximo dos trios elétricos (carros de som a partir dos quais as músicas de carnaval são tocadas) e outros lugares dotados de melhor infraestrutura, normalmente subsidiados por acordos e parcerias entre empresas e Poder Público, são destinados àqueles que podem pagar. Ou seja, a questão não é apenas uma segregação socioeconômica, mas também racial: nesses espaços, negros não podem entrar, ainda que tenham condiçôes financeiras para isso. O destino de muitos, numa sociedade 
10 Para conferir tal embate, ver: Blocos (2015) e Pacelli (2015). midiatizada pela televisão e aparelhos celulares que produzem imagens em tempo real, é ver tais eventos ou de muito longe ou pelas telas cotidianas, fechando um círculo de desestetização-reestetizaçáo da festa apenas pelo olhar, pela visualidade, pela imagem construída e televisionada.

Mas a camarotização é apenas o início do processo ou uma metáfora de um processo de produtivizaçáo da festa como possibilidade de sair do cotidiano para uma festa repetida, paulatinamente, todos os anos. Escolas de samba tornaram-se negócios multimilionários subsidiados ou por práticas ilegais como o jogo do bicho, ou por diversas marcas corporativas das mais diferentes naturezas, ou pelas próprias redes de televisão que pagam para que possam veicular os desfiles patrocinados. Rainhas da bateria e passistas são postos vendidos no mercado de celebridades como moeda de troca de apariçóes na mídia, a fim de tornar o desfile o centro de uma passarela, um espetáculo (CONHEÇA, s.d.).

O Poder Público adere a tal prática não apenas separando e construindo um espaço para os desfiles das escolas de samba, mas também reorganizando a circulação da cidade em prol da produtividade econômica, política e social do carnaval. Organiza: o transporte público para funcionamento durante o feriado, tendo a preocupação de estabelecer rotas específicas para assegurar que a periferia fique no carnaval a eles destinados na mesma periferia; o fechamento de algumas ruas; os banheiros públicos; as áreas para propaganda das mais diversas marcas, para que ela mesmo, como empresa, lucre com a festa dita popular. Ao requisitar, antecipadamente, os nomes dos blocos aos folióes, os itinerários deles para produzir uma estimativa de público, a fim de que os riscos possam ser controlados, e ao disponibilizar informaçóes em um site para que os próprios folióes possam se organizar, montando sua programação, o Poder Público toma frente e coopta a festa popular, transformando-a em uma festa promovida e criada por ele. É notório o embate entre prefeitura de Belo Horizonte e blocos de carnaval sobre tal cooptação $0^{10}$, na medida em que a burocratização intercede no carnaval, transformando-o em festa permitida, e a ingerência do Poder Público, como uma tentativa de reproduzir, pela cooptação, o espetáculo infinitamente, como coloca Castro (2015).

\section{CARNAVAL E CARNAVAIS}

Ainda que o carnaval acima descrito seja midiaticamente muito presente, nos anos 2000, em uma série de cidades, como Belo Horizonte, São Paulo e Brasília, ativistas sociais interessados na luta pelo direito à cidade reuniram-se e organizaram blocos de carnaval que, ao longo dos anos, ganharam uma dimensão maior e visível nas ruas, tornando-se movimentos sociais efêmeros - um paradoxo. Nesse contexto, desde 2009, muito se fala a respeito de um renascimento dos blocos populares de carnaval de Belo Horizonte, nascidos com o objetivo de contraporem-se a uma política de privatização do espaço púbico pela administração municipal (DIAS, 2015). Embora se coloque em discussão esse chamado renascimento, bem como quem seria $(\mathrm{m})$ o(s) responsável(is) por ele - um embate entre Poder Público e empresas, de um lado, e coletivos, folióes tradicionais e blocos novos, de outro -, visto que o carnaval da cidade nunca deixou de existir, mas sim foi diminuindo e desaparecendo das mí- 
dias e mesmo do espaço público por total falta de espaço e promoção institucional e também pela própria falta de uma comunicação mais efetiva, fornecida e apropriada taticamente via redes sociais a partir de 2009, a questão a ser discutida, de fato, é o contexto em que se dá o ressurgimento do carnaval em Belo Horizonte.

O reaparecimento do carnaval belo-horizontino em 2009 relaciona-se a uma rede de afetos, abarcando desde questóes geopolíticas macro até as da realidade cotidiana das ruas, entre as quais podem ser elencadas: crise de 2008, iniciada nos Estados Unidos, mas que se alastrou por toda a Europa ao longo de 2009, movimentando o imaginário da sociedade civil para se organizar em prol da democratização da vida e reocupaçáo da cidade como um bem público, inaugurando um levante em torno do termo lefebvriano "direito à cidade"; fortalecimento das redes sociais, em razão de sua capilaridade e facilidade de intermediação na criação de novas coletividades e proliferação de informação; políticas públicas federais que promovem um intercâmbio dos estudantes brasileiros com universidades no exterior, revelando-lhes o espaço público como território a ser conquistado e ser de direito popular, algo notório em grande parte dos países europeus devido a seu histórico de lutas no espaço da cidade; visibilidade dada a uma juventude, organizada desde os primeiros movimentos anti-globalização ocorridos em Seattle e que se alastraram pelo Brasil, em torno de uma série de pautas, em especial mobilidade urbana; regime excepcional de "contenção" - termo cunhado por Haesbaert (2014) para discutir a sociedade da segurança e controle características do século XXI, a partir de concepçôes de Deleuze e Foucault sobre a sociedade de controle e a biopolítica, respectivamente -, caracterizado pela "[...] associação íntima entre dinâmicas de contenção (diretamente territoriais ou não) e práticas de evitação, de privação e/ou fuga, isto é, o contrário do enfrentamento efetivo, do combate, como se estivéssemos fugindo da problemática real" (HAESBERT, 2014, p. 216) - um tipo de regime reproduzido pelo prefeito de Belo Horizonte desde que foi eleito para o cargo. Ademais, a visibilidade da diversidade de carnavais e dos modos de fazer carnaval que começa a ser criada a partir desse ano na cidade de Belo Horizonte, sendo tão importante quanto os outros fatores supracitados. Ela catalisou tal carga afetiva, servindo de base para o fomento e a criaçáo de um dos eventos históricos mais importantes do Brasil neste início de século XXI: as Jornadas de Junho de 2013.

Num contexto local e municipal, esse renascimento popular e independente do carnaval ocorrido em 2009 e prolongado até hoje tem como seu contraponto a administração municipal da cidade Belo Horizonte, representada na figura do entáo prefeito Marcio Lacerda, que vem buscando capitalizar e controlar a manifestação carnavalesca. E durante as Jornadas de Junho de 2013, as manifestaçôes populares apontaram para a possibilidade de o carnaval ser não apenas uma festa passível de ser controlada pela prefeitura, mas também uma semente que, uma vez germinada, póe em xeque todo um modo de viver pela ocupaçáo das ruas. Em junho de 2013, nas ruas e pelas ocupaçóes das ruas, foi apresentada uma nova e expandida coleção de pautas que normalmente não se associam ao carnaval - transporte, meio ambiente, cultura, entre outros -, assim como um modo renovado de fazer política, no qual a população se sente corresponsável pelo planejamento e gerenciamento da cidade, a ponto de querer sair de uma posição consultiva para uma mais deliberativa e decisória, tal como sugere o professor de ciência política Leonardo Avritzer (2016), em seu recente livro Impasses da Democracia no Brasil, cujo tema é a relação entre participação, políticas públicas e o evento Jornadas de Junho de 2013, entendido como 
clímax da emergência da nova atitude da sociedade civil organizada. Especificamente em 2013, o modo de ocupar as ruas com danças, músicas e fantasias muito se assemelhou a dispositivos e açóes comumente usados durante o período de carnaval. Foi um carnaval: inversões de papéis foram feitas, com a multidão nas ruas assumindo o protagonismo, sem uma figura de liderança; identidades e coletividades produzidas, sem uniformes ou outras imagens de cooptação (RICCI; ARLEY, 2014); novos lugares de fala foram inaugurados pelo uso de redes sociais e produção de canais de comunicação via Facebook e outras mídias sociais (SILVA, 2014).

A prefeitura vem tentando se aproximar do carnaval para controlar e gerenciar riscos e contingências: ela delimita áreas onde ele pode ou não ocorrer, a fim de impedir que as grandes avenidas sejam ocupadas; dá suporte para que o carnaval ocorra (vide a disponibilização de contingente policial e secretarias para fornecimento de infraestrutura e segurança para os blocos); permite/vende o carnaval como produto feito por ela mesma para companhias multinacionais, que estampam suas marcas e vendem seus produtos exclusivos. Essa última medida vai contra: o desejo dos blocos populares responsáveis pelo renascimento do carnaval de Belo Horizonte em 2009 (MACHADO, 2015); “[...] os tipos preconceituosos e sexistas de mensagens que tal patrocínio pode trazer como ocorreu com a campanha 'Deixei o não em casa”" (LAFLOUFA, 2015); pautas públicas como a do coletivo Tarifa Zero nascido em 2013, que argumenta que a criação de uma linha de ônibus específica para o evento, composta de 14 ônibus para circular entre os blocos nos dias de festa, é mais uma ação que visa a sublinhar a mobilidade como questão privada e não pública, além de desmobilizar e despolitizar a açáo feita nos dois anos anteriores, a partir da qual o coletivo contrata e disponibiliza à cidade durante o carnaval ônibus gratuito, o Buzona (SILVA, 2016). Ao pedir que os blocos populares se inscrevam antecipadamente no site da Prefeitura Municipal de Belo Horizonte (BH, 2013), no intuito de fazer uma cartografia dos blocos, produz-se uma informação que permite um maior controle do que ocorre, quando ocorre, racionalizando custos e tornando funcional a própria festa, que deveria ser espontânea, popular e disfuncional, uma celebraçáo da cidade como lugar a ser ocupado por todos, sem a necessidade de pedir permissão.

O intento da prefeitura, ao vender o carnaval como produto, é transformar os carnavais em um carnaval que celebre a mineiridade, marca estadual que não permite novos significados para o que significa ser mineiro. Nisso se observa a identidade nacionalista como camisa de força do que virá, como dizem muitos dos estudiosos culturais sobre a relação entre essa e outras políticas públicas de controle e fomento - gerenciado - da cultura.

Entretanto, o carnaval se notabiliza como festa única não pela unicidade do nome, mas pela pluralidade e diversidade de manifestaçóes, observadas nas roupas, nas músicas, na bateria, na participação aberta, no modo de ocupar a rua e no conteúdo político. A cada tentativa de apropriação do carnaval pelos agentes do Poder Público e do poder privado, novos carnavais são inventados. A cada ano, mais blocos são criados, os quais ocupam seus lugares no espaço da cidade, pouco importando se grandes ou pequenos, a ponto de a própria prefeitura se pronunciar, abordando negativamente o fato de os blocos populares de carnaval náo pararem de crescer, a despeito das tentativas de controle e previsão.

Em Belo Horizonte, o carnaval do desfile de escola de samba ou patrocinado pela prefeitura como imagem unificadora do que significa a festa carnavalesca é subs- 
tituído pela multiplicação dos carnavais, pois a quantidade de blocos e os modos de fazer carnavais só se multiplicam. Enquanto em 2009 eram apenas quatro blocos esparsos pela cidade (Bloco Tico Tico Serra Copo, Então Brilha, Baiana Ozadas e Trema na linguiça), em 2015, numa carta de repúdio à privatização do carnaval, ficou claro o aumento exponencial de blocos independentes do Estado e populares: Alcova Libertina, Alo Prado, Approach, Angola Janga, Baianas Ozadas, Baiáo de Rua, Baque de Mina, Bloco aki cê dança, Bloco da Bicicletinha, Bloco da Praia, Blocomum, Bloco Coco da Gente, Bloco do seu Pai e filhos de Gaby, Bloco Duro, Bombos de Iroko, Beiço do Wando, Bloco da Calixto, Bloco do Cuei, Bloco Fúnebre, Bigode Cheiroso, Bom Bloquiu, Corte Devassa, Cuequinha do Papai, Delírio Coletivo, Do seu Bento à Dona Lúcia, Então Brilha, Fera Neném, Filhos de Tcha Tcha, Filhos de Olorum, Golobloco, Juventude Bronzeada, João Careca, Língua do São Salvador, Mama na Vaca, Manjericão, Maria Baderna, Moreré, Me assume ou me esquece, $\mathrm{Me}$ beija que eu sou pagodeiro, $\mathrm{O}$ pior bloco do mundo, Ordináááários, Padecendo no paraíso, Pena de Pavão de Krishna, Peixoto, Pisa na Fulô, Pula Catraca, Queixinho, Tico Tico Serra Copo, Tchanzinho da Zona Norte, Tetê, a Santa, Toca Raul, Agremiação Psicodélica, Unidos da Estrela da Morte, Unidos do Queima largada, Vai tomar no Cooler, Vira o Santo. Acrescente-se que a multiplicaçáo de blocos formados por proximidades territoriais - como o Tchanzinho da Zona Norte, por ideologias, como o Blocomum e Bloco da Bicicletinha, por causas, como as ocupaçóes urbanas na cidade, representadas pelos Filhos de Tcha Tcha, entre outros - só expóe os modos como a festa carnavalesca é diversa, não porque os nomes deles são diferentes, mas porque expressam maneiras diferentes de produzir a própria festa: um em derivas pela cidade em bicicletas, outro, por caminhadas nas zonas periféricas do município, e assim por diante.

Multiplicidade paradoxal, pois, por exemplo, componentes do Bloco Tico Tico Serra Copo são os mesmos que participam do Bloco Filhos de Tcha Tcha. Isso mostra como as coletividades e suas identidades são fugidias e performáticas, na medida em que são sempre as mesmas pessoas organizando-se de variadas formas para reconstruir outras formas de ocupar os espaços, cada qual de uma maneira. Enquanto o primeiro bloco leva seus foliôes a espaços recônditos da cidade de Belo Horizonte para mostrar áreas desconhecidas aos próprios habitantes da cidade, como aconteceu em 2015, quando foi feito o percurso do bairro São Geraldo até chegar a uma cachoeira no limite do município, ou em 2016, quando a trajetória do bloco conduziu a uma praia às margens do rio do Onça, na regiâo do bairro Ribeiro de Abreu; o segundo leva a derivas pelas ocupaçóes urbanas da cidade para ver e incorporar ao carnaval regiôes segregadas e consideradas ilegais pelo Poder Público. Enquanto o primeiro bloco se interessa pelos caminhos das águas da cidade, o segundo se atenta para as lutas urbanas. Em ambos, a bateria aberta é o componente que une: um grupo de músicos que aceita qualquer pessoa, sem nenhuma educaçáo musical anterior, como membro para tocar marchinhas de carnaval ou funks enquanto se caminha e festeja.

Os folióes vestem-se não de identidades estereotipadas como super-heróis ou índios, em vez disso, fazem uma bricolagem de roupas, cujo resultado final nada é senão uma colagem que não se parece com nada. Pintando o rosto de azul, como fazem no bloco Pena de Pavão de Krishna, vestindo folhas de bananeira, no bloco Tico Tico Serra Copo, e assim por diante, eles jogam e criam a si mesmos. O vestir-se é jogar com as identidades, performatizar o corpo, criar imagens únicas de si. Criar tais 
personas num contexto de produçáo de coletividades, novos espaços e modos de usar a cidade significa abrir o imaginário para o que pode vir a ser possível

\section{DO CARNAVAL À CARNAVALIZAÇÃo}

O carnaval de Belo Horizonte é sinônimo, como os próprios integrantes dos blocos de carnaval de rua autoproclamam-se, de carnaval de luta. Carnaval de luta, nome de uma comunidade existente no Facebook (CARNAVAL DE RUA, 2009), não é apenas de luta porque enfrenta e se opóe à prefeitura de Belo Horizonte e suas tentativas de capitalização do evento festivo, mas também porque é contra a normalização da vida. Nesse site, compreendido como plataforma ou território que torna visível movimentos, grupos e espaços de luta que normalmente náo têm representaçáo dentro do Poder Público e Estado, constitui-se um espaço de dissenso. Mais ainda, um espaço de visibilidade minoritária que o Estado e a grande mídia insistem em tornar invisível.

Tampouco um espaço de luta para derrotar o Estado. Ao contrário, é uma luta que implica a manutenção do outro como adversário, numa prática agonística que não quer a destruição, mas sim aliança para a construção de novos territórios de discussão entre Estado e movimentos sociais - estes entendidos não apenas como entidades ou institucionalidades, mas também como movimentaçôes sociais. As políticas públicas que reconheciam esses outros espaços de produção discursivos resumiam-se, até início dos anos 2000, a organismos protetores dos direitos humanos, sendo o termo "direitos humanos" tudo aquilo que não é reconhecido por políticas que não dão conta de sua nomeação. Assim, mesmo mantendo secretarias ou gerências de "direitos humanos" como espaços para o povo - aquele inominável e exemplar, último bastião de proteção da vida nua que, segundo Agamben (2015a), quer fazer desaparecer paradoxalmente -, é perceptível que as políticas municipais têm se direcionado ao reconhecimento de públicos específicos: comunidades tradicionais, moradores de favelas, lésbicas, gays, bissexuais, travestis, transexuais e transgênero (LGBT), entre outros. Públicos que, muitas vezes, apareciam apenas como fantasias de carnaval de morador de rua, travesti e índio, por exemplo, tornam-se objetos de políticas públicas - a fantasia se torna objeto de discussão, pois aponta para algo real. A prefeitura, a partir de políticas públicas e açôes de planejamento urbano, vai sendo carnavalizada através da luta, incorporando demandas e abrindo-se a práticas políticas socioespaciais menores por meio da invenção de políticas públicas interessadas na discussáo e no reconhecimento da diversidade. Assim, a luta pela visibilidade é tanto para se opor a um Estado que a desconsidera, bem como para construir uma força política que a torne questão de Estado, sem o substituir. Uma aliança carnavalizadora, não indiferença.

Conforme dito anteriormente, a democracia e a política só podem ocorrer em

11 Ainda que não tenham direitos e políticas públicas específicas, é inegável que o desenvolvimento da visibilidade da questão LGBT tenha alcançado avanços. Um deles é o fato de haver na página da prefeitura uma chamada para a 18a edição da Parada do Orgulho LGBT. dois registros que parecem paradoxais ao ocuparem uma mesma estrutura: o da ação direta e o da representação política. Grupos vinculados à causa LGBT, por exemplo, lutam pelo direito à diferença e pelo reconhecimento dela por organismos representativos dentro do Estado ${ }^{11}$, além de lutarem nas ruas em manifestaçóes contra a morte de travestis (MANIFESTAÇÃO, 2013) e em açóes como a Gaymada (PIMENTEL, 2015), jogo de queimada organizado nas redes sociais por grupos LGBT, principalmente. Um evento aberto, com fantasias, músicas, com presença da bateria percurssi- 
va tocada por pessoas e por meios eletrônicos (laptops), que se resumiu ao desenho de uma quadra e a um jogo de queimada - as ediçóes ocorreram na Praça da Liberdade e no Parque Municipal num domingo. No entanto, durante o jogo, palavras de ordem, gritadas ao microfone, pedindo reconhecimento, menos preconceito e direito à cidade, usavam como temas de base perguntas proferidas em alto som, como: "Voce, aí, tem um amigo transexual?", "Voce sabia que Belo Horizonte é a cidade que mais violenta pessoas LGBT?”.

Como resultado, a prefeitura da cidade de Belo Horizonte vem paulatinamente tornando visível a discussão LGBT, por meio de uma série de açôes advindas da luta exposta no carnaval. O Estado se carnavaliza ao abrir-se a frentes de discussão da multiplicidade, nesse caso, sexual. Dando representatividade à questáo através da organizaçấo de fóruns de discussão sobre diversidade sexual, identidade de gênero, homofobia, lesbofobia e transfobia e políticas públicas nas regionais da cidade desde 2015 - tudo isso dentro do Programa BH sem Homofobia -, a cidade se abre ao que antes só podia ser objeto de brincadeira durante os cinco dias de carnaval: a experimentação e produçáo de identidades. Na $2^{\mathrm{a}}$ Conferência Municipal de Direitos Humanos e Cidadania LGBT, ocorrida entre 18 e 19 de setembro de 2015, organizada pela prefeitura de Belo Horizonte, já se antevia a necessidade de criar uma Coordenadoria Municipal LGBT, um Conselho Municipal LGBT, bem como a demanda pela garantia jurídica do uso do nome social por travestis e transexuais nos serviços públicos municipais $^{12}$.

Um outro exemplo é a premência que a questão da mobilidade adquire durante os cinco dias de carnaval e como ela é abordada pelo Estado como política pública no restante do ano, a partir de pressóes populares. A mobilidade é uma questáo central porque, para participar do carnaval distribuído pela cidade, é necessário um meio de transporte que leve os folióes de uma parte a outra, de um bloco a outro. O movimento Tarifa Zero criou o Buzona para fazer tal trajeto gratuitamente durante os dias de carnaval, no entanto, em 2016, a prefeitura de Belo Horizonte vendeu a ideia, como se fosse dela, a uma fábrica de bebidas. Mesmo após o carnaval, o imaginário de uma linha de ônibus gratuita se instalou como possibilidade de construção de um novo modo de viver na cidade, e o vereador Adriano Ventura propôs o polêmico projeto de lei 1.966/2016, cujo objetivo é tornar gratuita as viagens de ônibus aos sábados, domingos e feriados (LOBATO, 2016b). Ainda que a aprovação seja difícil, pois ela tem como barreiras o lobby das empresas viárias, muito fortes politicamente e vinculadas à prefeitura municipal, a proposta só aponta para o modo pelo qual o planejamento da cidade é carnavalizado por práticas e demandas que surgem no carnaval.

A estratégia do carnaval é replicada por outros eventos de cunho carnavalesco que ocorrem durante o ano, fazendo do ato carnaval uma festa ou feriado de cinco dias no mês de fevereiro, assim como estratégia e exercício de uma democracia paradoxal. O carnaval de luta acontece o ano inteiro na rua, porque esse é o espaço público comum a todos, sendo náo apenas um espaço para ocupar, mas também para tornar visíveis outras modalidades de uso; é na rua porque é popular e aberto a qualquer um que se sinta afetado pelas demandas e pela luta em processo; e o carnaval só pode ocorrer pela luta, uma vez que seu conteúdo político só pode se expressar como exercício de cidadania no momento em que questôes individuais tornam-se questóes de cunho público ${ }^{13}$.
12 Para mais detalhes dos resultados da $2^{\text {a }}$ Conferência Municipal de Direitos Humanos e Cidadania LGBT, ver: Prefeitura de Belo Horizonte (2015).

13 É interessante a maneira como Giorgio Agamben (2015b, p. 12-13) pensa a questão da cidadania a partir do caso da Grécia Antiga, onde esse titulo não é dado pelo Estado ou pelos políticos, só existe como exercício de politização cotidiana na relação entre polis (cidade/público) e oikos (casa/privado). Ser cidadão não é ser reconhecido juridicamente como pertencente a esta ou àquela nação ou povo, como um dado imanente, mas sim um momento contingente em que o indivíduo luta por questões de interesse público, a despeito de uma pertença anterior. 


\section{MAIS CARNAVAIS}

Para implementar a carnavalização da política e do Estado internamente, a partir do planejamento urbano e suas políticas públicas, a construção de novas representaçôes, de novos nomes, novos povos e de novos modos de viver precisa ser continuamente garantida pela luta nas ruas (asfaltadas ou virtuais). Novas subjetividades precisam ser criadas, aliadas à capacidade de construir um novo imaginário de cidade efetivamente possível. Novos carnavais, inclusive dentro dos muitos carnavais já expostos acima, estão em gestação. Carnavais que vêm para diferir de outros, para criar novos campos de atuação e novas subjetividades e olhares sobre a cidade.

Quando em dezembro de 2013 foram iniciados os "rolezinhos", "[...] agrupamento[s] de jovens que se reúnem em shoppings, parques e lugares de fácil acesso ao público a fim de se divertirem, fazer novas amizades, e interagir em um ambiente social totalmente diferente da realidade social em que eles vivem" (SILVA, 2016), uma nova possibilidade de lazer foi imaginada. Náo que a ida a shoppings centers pelos moradores da periferia já não acontecesse, o surpreendente da ação foi seu volume e onde aconteceu: mais de mil pessoas ocupando um espaço de shopping center num mesmo momento, como um flash mob; as vestimentas dos jovens não eram as mesmas dos ocupantes habituais dos shoppings; o lugar do encontro eram os shoppings das zonas mais abastadas da cidade e não os periféricos, que os isolava do excedente da cidade, localizado no centro - o centro econômico, político e cultural materializado em centro culturais, museus, espaços públicos de qualidade, fácil acesso por meio de uma rede de transporte público. Nesse último caso, é interessante lembrar que, analogamente, durante as ocupaçóes das escolas de Sáo Paulo em 2015, movimento feito contra a reorganização escolar proposta pelo governador Geraldo Alckmin, uma das questôes que provocaram a ação por parte dos alunos foi o fato de que estudar numa escola no centro da cidade abria os horizontes dos alunos que habitavam a periferia. O movimento pendular de suas áreas de morada, precárias e sem infraestrutura, para o centro, onde uma série de estruturas culturais existiam, possibilitava-lhes o acesso a informaçóes e a um contexto cultural que não alcançariam se ficassem isolados em seus bairros. A luta era pela cidade.

Assim, o "rolezinho" como estratégia de errância urbana - quebrando caminhos já definidos e segregaçóes espaciais e expondo uma mobilidade que não quer ser pensada apenas de maneira funcional, mas também como forma de acesso a equipamentos, inclusive de consumo, sendo o próprio consumo sinônimo de cidadania, como atestam os estudos do culturalista Néstor García Canclini $(2007 ; 2008)$ e de Homi K. Bhabha (2008) - aponta para uma subjetividade em que a questáo política e democrática é vivida, ainda que não seja formulada de maneira consciente e articulada.

A compra por parte dos moradores da periferia de bens de consumo domésticos durante os governos progressistas do Partido dos Trabalhadores (PT) - de 2003 a 2016, nos governos de Luiz Inácio Lula da Silva e Dilma Rousseff, respectivamente - produziu, a reboque, uma bolha democrática, como demonstra Gomes (2014). Se o desejo pelo consumo foi saciado, a mesma afirmação não pode ser feita, segundo Costa (2014), para o caso do desejo por reconhecimento via bens coletivos e públicos como praças, parques e opçóes de lazer. A bolha democrática é justamente o desejo de reconhecimento como cidadáo, que passa pelo atendimento a direitos coletivos e 
públicos, e não somente a direitos individuais. $\mathrm{O}$ desejo de inserção social e o radical reconhecimento de si como cidadão por meio da identidade de consumidor gerou uma expectativa que produziu uma nova luta por espaços, encontrando no caso dos shoppings centers seu epicentro: um equipamento de consumo (individual) e também de lazer (coletivo) em que práticas sociais distintas conflagram uma guerra territorial mediada pela polícia, porque a política ali inexiste. Tal como o carnaval, que ocupa o espaço de circulação de mercadorias, no caso, a rua, o "rolezinho" faz a mesma coisa.

No carnaval de Belo Horizonte em 2016, um "rolezinho" aconteceu e outro foi impedido. No primeiro caso, na praça $\mathrm{ABC}$, no centro da regiáo da Savassi, localizada na regional Centro-Sul, um dos principais pontos do carnaval de rua para as classes médias e altas, a mudança no perfil dos foliôes e no tipo de festa carnavalesca provocou um conflito, segundo a polícia, pela alteração do tipo de música (do samba para o rap), dos carros (dos importados para os modelos mais velhos, modificados para serem algo similar a um trio elétrico, com um potente sistema de som interno), das pessoas (de uma maioria branca para uma maioria negra) (LOBATO, 2016a). Por sua vez, na estaçáo do metrô Primeiro de Maio, o "rolezinho" carnavalesco da zona norte foi impedido de continuar porque a Companhia Brasileira de Trens Urbanos (CBTU) decidiu fechar suas portas mais cedo, não permitindo que o movimento do bloco carnavalesco fosse em direção às áreas não acordadas ou informadas previamente (FOLIA, 2016). Esses dois "rolezinhos", mais do que deslocamentos em direção a regiôes sempre destinadas a uma elite, configuraram-se, objetivamente, como criaçôes subjetivas da bolha democrática, na qual o espaço para poucos seria ocupado pelo povo que desejava visibilidade, reconhecimento, aceitação e acesso a bens de consumo simbólicos e materiais que os distinguiam dessa regiáo da cidade. Os "rolezinhos" são uma criação de Situaçóes festivas - uma politização da vida contra a estetização da cidade. São um sintoma de que os blocos de carnaval existentes são uma invenção que não consegue satisfazer a todos, pois todos são muitos. Por essa razão, mais blocos devem ser inventados pelo deslocamento de identidades já dadas. Ou as identidades devem ser continuamente inventadas a partir da inoperacionalizaçáo das anteriores.

De acordo com Agamben (2011), a inoperosidade é uma estratégia própria da linguagem poética, a partir da qual se tornam inoperantes ou se póem fora de ação determinados códigos linguísticos, anulando a capacidade biopolítica da língua de dominar e normalizar gestos e simbolismos ao considerá-la território de disputa para a criação de novos coletivos, novos aglomerados, novos bandos em forma de alianças, novos agenciamentos e novas representaçôes, inclusive do que ainda não é passível de ser nomeado pela sua consequente nudez. Profanando os lugares de exercício de poder e seus dispositivos, inoperacionalizando lugares estáveis e exigindo deles, pela luta, novas configuraçôes territoriais inclusivas, o objetivo é permitir a criação de novas festas, novos modos de viver. O "rolezinho" é um sintoma das limitações dos blocos de carnavais populares e espaços carnavalescos, na medida em que eles não conseguem agregar a todos. Quando o Tchanzinho da Zona Norte não pôde "dar um rolé” para além de seus lugares cotidianos, isto é, a própria zona norte de Belo Horizonte, sua força como bloco criativo desapareceu, porque um novo lugar não pôde ser inventado. Ele teve de se contentar em continuar sendo um bloco estático e preso à zona norte, em detrimento das derivas realizadas nos anos anteriores pela cidade. $\mathrm{O}$ "rolezinho" da periferia até a praça $\mathrm{ABC}$ tornou momentaneamente inoperante 
14 Disponível em: <www. mapadafolia.com.br $>$. Acesso em: 4 maio 2016. o carnaval da prefeitura e da zona sul, para transformá-lo em outro, com seu funk e carros sonoros, ao menos até o momento que a polícia não havia soltado suas bombas de gás lacrimogêneo. A alteridade é tudo o que o Estado não deseja, e o "rolezinho" é uma pratica que aponta sempre para uma multiplicação de carnavais, de alteridades, negando tanto o Estado como as identidades carnavalescas capturadas, seja pelos foliōes, seja pela prefeitura, seja por empresas.

Assim, sites de foliôes ou jornalistas independentes como o Mapa da Folia ${ }^{14}$, cujo objetivo é revelar não apenas a localização dos blocos como também produzir ensaios de escrita a partir do que ocorre dentro deles, dando uma cartografia, em tempo real, das subjetividades e dos afetos em movimento, de perto e de dentro, apresentam, a partir de um olhar singular e participante, implicado politicamente nesse ritual festivo, vivências que se transformam em experiências produtoras de novas e outras subjetividades. Mais ainda, discursam sobre experiências de deslocamento, de encontro, de estranhamento e maravilhamento com o diferente, algo que se configura como sinônimo de festa:

Ter experienciado aquela chuva entre as ocupaçôes fez pensar - mais uma vez, e para sempre - em privilégios, desigualdades, lugares de fala, lugares de vida. Em condições de sobrevivência e resistência, mas, acima de tudo, na força do coletivo. Nas casas enquanto células que juntas se fazem vivas. Nos moradores como guerreiros que sabem o quanto se precisam, e o quanto se fazem maiores por isso. Em cada pessoa que fez feijáo tropeiro, embalou chup chup, colocou cerveja para gelar, soprou trompete, deu tchau pela janela, tocou surdo e caixa e repique, pintou criança, ajudou a descer sem cair, escorregou sem perder a áurea, apitou pulmóes afora, sentiu peito adentro; e na experiência mais potente e humana de carnaval que elas - juntas, sempre, e não haveria outro jeito de ser - criaram na vida de muita gente (BRAGA, 2015, n.p).

\section{DO CARNAVAL À GUERRA}

A deflagraçáo do carnaval como evento vivido e absorvido pelo planejamento urbano fora de época traz outra discussão: a contaminação subjetiva carnavalesca que o evento é capaz de produzir por meio do contágio das várias formas de viver em sociedade pela modalidade democrática - portanto, formas de política que o carnaval absorve e produz de maneira renovada. Um contágio que é a produção de um novo modo de operar na cidade, diferente daquela que deseja ser reflexo do espetáculo; um contágio em que o "rolezinho" é a principal estratégia,

Michel Foucault faz, no século XX, uma releitura da relação entre guerra e política feita pelo general Carl Von Clausewitz em sua análise da natureza desse tipo de conflito armado no século XIX. Enquanto o estrategista alemão escrevia sobre a guerra como um evento excepcional que tem lógica e racionalidades próprias e que, uma vez terminada, teria continuidade como política, Foucault (2005) pensa e compreende a política como uma continuidade da guerra pela absorção de conflitos para dentro do aparelho de Estado, como pode ser visto Em Defesa da Sociedade. Isso significa que, para o filósofo francês, as estratégias de planejamento estatal perpetradas desde sempre na Modernidade vêm não para prover maior justiça social e diminuir 
desigualdades, mas para manter conflitos provocados de maneira tensionada e silenciosa, sempre visando a conservar uma desigualdade de condições. Portanto, o conflito próprio da democracia não existe na acepção de guerra foucultiana, pois a política advinda da guerra pelo filósofo vem para suprimir conflitos visíveis e históricos e, calculadamente, para controlar os riscos da emergência da biopolítica como meio de controle das pulsôes coletivas e populacionais. Na política advinda da guerra não há democracia, apenas autoritarismo disciplinador.

O antropólogo francês Pierre Clastres (2011), na mesma época que Foucault escreve sobre a guerra, produz um texto interessante sobre a mesma questão, qual seja, Arqueologia da Violência: A Guerra nas Sociedades Primitivas. Nesse texto, ele explora as diversas formas de pensar e agir a partir da ideia de conflito gerenciado pelo Estado. Se a guerra na Modernidade, pela leitura de Foucault, aparece como um conflito silenciado dentro do Estado, para Clastres, no contexto das sociedades ameríndias estudas por ele, isso não ocorre, porque, primeiramente, a sociedade indígena é contra o Estado. Em A Sociedade contra o Estado, do livro homônimo, Clastres (2013) demonstra como a própria sociedade indígena é estruturada, em sua base econômica e política, como uma sociedade que náo consegue pensar e construir-se a si mesma a partir de uma estrutura exógena, a saber, o Estado. Com uma economia de subsistência que não produz excedente, logo não objetiva o lucro, e com uma estrutura de poder que privilegia não a hierarquia e a verticalidade, mas a individuação, a horizontalidade e o lugar de poder como lugar vazio, porque submetido à vontade de todos, Clastres, a partir de suas experiências antropológicas com povos ameríndios, comprova a existência de outros modos de viver em que o Estado pode não existir. Uma forma de vida na qual o Estado é uma estrutura a ser combatida cotidianamente.

Em segundo lugar, a guerra não é conflito adversarial, segundo mostra Clastres a partir de uma perspectiva calcada nas sociedades ameríndias. A guerra, nas sociedades ameríndias, não é traço histórico, como Foucault atesta em suas pesquisas, mas traço natural que define o ser índio. Nas palavras do antropólogo, o índio é ser-para-a-guerra, o que implica que a guerra não é continuidade de nada senão uma ontologia indígena. Tal guerra não é afirmação de si, mas de uma diferença. Não à toa, ele apresenta o paradoxo da guerra ameríndia: afirmação de uma unidade e totalidade em que existe diferença.

Portanto, a lógica da sociedade primitiva é uma lógica do centrífugo, uma lógica do múltiplo. Os selvagens querem a multiplicação do múltiplo. E qual é o efeito principal exercido pelo desenvolvimento da força centrífuga? Ela opóe uma barreira intransponível, o mais poderoso obstáculo sociológico à força inversa, à força centrípeta, à lógica da unificação, à lógica do Um. Por ser sociedade do múltiplo, a sociedade primitiva não pode ser sociedade do Um: quanto mais houver dispersão, menos haverá unificação.

$[\ldots]$

A dispersão dos grupos locais, traço mais imediatamente perceptível da sociedade primitiva, não é portanto a causa da guerra, mas seu efeito, sua finalidade específica. Qual a função da guerra primitiva? Assegurar a permanência da dispersão, da fragmentação, da atomização dos grupos. A guerra primitiva é o trabalho de uma lógica centrífuga, de uma lógica da separaçấo, que se exprime de quando em quando no conflito armado. A guerra serve para manter cada comunidade em sua independência política. Enquanto houver guerra, há autonomia: é por isso que ela não pode, não deve cessar, é por isso que ela é per- 
manente. A guerra é o modo de existência privilegiado da sociedade primitiva enquanto esta se distribui em unidades sociopolíticas iguais, livres e independentes: se não houvesse inimigos, seria preciso inventá-los (CLASTRES, 2011, p. 247-248).

As manifestaçóes carnavalescas, tanto de blocos, como a do Bloco da Bicicletinha e do Tico Tico Serra Copo, quanto os "rolezinhos" da periferia, são movimentos que vêm para afirmar um devir fragmentário, porque, desde 2009, tais blocos e "rolezinhos" só se multiplicam, ao mesmo tempo, elas também afirmam uma autonomia própria. Em guerra contra o Estado e também contra o estatismo de ser "si mesmo", tais blocos criam e asseguram que muitos são diversos, tendendo a um devir infinito.

No território chamado Brasil, ou presente na ideia de povo mineiro ou de brasilidade, as imagens nacionalistas e unificadoras advindas desses ideais sempre existem para acabar com o que desvia e "dá um rolé". Belo Horizonte é sempre definida como uma cidade símbolo da mineiridade, do progresso, como foi seu objetivo desde que construída no meio do nada, em fins do século XIX. No entanto, se se toma o carnaval como paradigma para narrar Belo Horizonte, sobretudo a partir de 2009, a cidade existe não como bloco estático, mas como um horizonte sempre fugidio. Belo Horizonte sempre está em guerra, porque, a despeito de suas imagens colonizadas pelo espetáculo biopolítico, ela existe para a guerra.

\section{À GUISA DE CONCLUSÃO: BELO HORIZONTE- PARA-A-GUERRA}

Ainda que a prefeitura de Belo Horizonte e o Estado pareçam agir para unificar, homogeneizar e absorver tudo o que lhe é diverso, é preciso lembrar, como bem diz Souza (2002), que o Estado não é um bloco liso e impenetrável, mas cheio de reentrâncias e buracos, e, por isso, permissivo a outras formas de exercer política, inclusive algumas interessadas em formas mais autônomas de exercício de cidadania. E o carnaval como festa tem objetivos democráticos claros no contexto aqui discutido: produzir não formas de resistência, mas formas de vivência pela ação direta no espaço ou pela representação do povo. Assim, o Estado e sua forma institucional pública, a prefeitura, podem absorver essas novas formas ou carnavalizá-las pela pressão exercida por movimentos sociais e sociedade civil.

Os blocos de carnavais em Belo Horizonte perceberam tal abertura pela luta e pressão popular, assim como pelo imaginário introduzido por táticas carnavalescas. Os blocos vão transmutando-se e produzindo novas formas de ação em diferença. Movimentos e coletivos, como o Tarifa Zero, o BH em Ciclo, o Muitxs - Pela Cidade que Queremos, o Espaço Comum Luiz Estrela, entre outras entidades políticas, nada mais são do que desdobramentos e devires advindos, respectivamente, dos blocos carnavalescos Tico Tico Serra Copo, Bloco da Bicicletinha, Filhos de Tcha Tcha, Blocomum. Esses devires compreendem que a dimensão alegre do carnaval é mais do que identidade visual, é uma forma de produzir um imaginário daquilo que pode vir a ser uma nova forma de viver e de se apropriar da cidade. Sáo coletividades que não apenas resistem ao Estado, mas também acabam por carnavalizá-lo: a pressão por mais espaços para os ciclistas no centro da cidade através de manifestaçóes (OLIVEIRA; KIFER, 2014) e também de invençôes, tais como: as bicicletadas noturnas, que 
comprovam o uso do espaço e forçam o Poder Público a perceber que esse espaço é usado e precisa ser ampliado e discutido como política pública (PIMENTEL, 2016), como acabou sendo feito, ainda que timidamente, nos últimos anos; a cessão, por parte da prefeitura, de um casarão antigo abandonado para ser autogerido, como é o caso do Espaço Comum Luiz Estrela (CRUZ et al., 2013), em resposta à sua ocupaçáo durante as Jornadas de 2013; os movimentos municipalistas que propóem formas mais abertas e participativas de fazer políticas partidárias e de planejamento e gestão da cidade (MIRANDA, 2016); entre outros.

Adensar o movimento de carnaval e carnavalizar o planejamento urbano significa produzir misturas, provocar alianças, criar bandos, construindo espaços diferenciais e inventando novos territórios a partir da contaminação dos diversos saberes produzidos pelas roupas, pelas músicas, pelos modos e costumes dentro e fora do Estado. Belo Horizonte-para-a-guerra é a ontologia de cada cidade pelo seu tecido social, sendo sua tendência. Ela é única e total, mas sempre se multiplica, porque é seu devir intrínseco.

Se tal resistência carnavalesca é da ordem do afeto - e somente se constrói por aí-, de que modo pensar um Estado que caminhe nessa direção e que se baseie nisso como uma epistemologia é uma questáo central. Um Estado que tenha como projeto o carnaval como agenciamento social de produção do espaço. Um afeto não romantizado e que possibilite uma política do conflito em que a democracia não seja um paradigma, mas uma prática a ser construída pelo embate e pelo encontro com o diverso.

\section{REFERÊNCIAS}

AGAMBEN, G. O Reino e a Glória. Uma genealogia teológica da economia e do governo. São Paulo: Boitempo, 2011. . Meios sem Fim. Notas sobre a potência. Belo Horizonte: Autênctica, 2015a. . Stasis. Civil war as a political paradigm. London: Edinburgh University Press, 2015b. AVRITZER, L. Impasses da democracia no Brasil. Rio de Janeiro: Civilização Brasileira, 2016. BAHBA, H. O local da cultura. Belo Horizonte: Ed. UFMG, 2008.

BENJAMIN, W. A obra de arte na era de sua reprodutibilidade técnica. In: Magia e técnica. Arte e política. Obras Escolhidas. v. 1. São Paulo: Brasiliense, 1985.

BH abre inscrição de blocos de rua para Carnaval em 2014. Portal EBC, 22 dez. 2013. Disponível em: <http://www.ebc.com.br/cultura/2013/12/bh-abre-inscricao-deblocos-de-rua-para-carnaval-em-2014>. Acesso em: 4 maio 2016.

BLOCOS de rua publicam manifesto contra apropriaçáo comercial da folia. Santa Tereza tem, 27 fev. 2015. Disponível em: <http://santaterezatem.com.br/index.php/2015/02/27/blocosde-rua-publicam-manisfesto-contra-apropriacao-comercial-da-folia/>. Acesso em: 5 maio 2016.

BRAGA, C. B. Nuvem carregada de gente desaguando em terra. Mapa da Folia, 20 fev. 2015. Disponível em: <http://www.mapadafolia.com.br/2015/02/20/nuvemcarregada-de-gente-desaguando-em-terra/>. Acesso em: 4 maio 2016.

CANCLINI, N. G. Consumidores e Cidadãos. Rio de Janeiro: Ed. UFRJ, 2007. Diferentes, Desiguais e Desconectados. Rio de Janeiro: Ed. UFRJ, 2008.

CARNAVAL DE RUA BH. Pagina Facebook Carnaval de Rua, 2009. Disponível em: <https://www.facebook.com/carnavalderuaBH/info/?entry_point=page_nav_about_ item\&tab=page_info>. Acesso em: 4 maio 2016.

CASTRO, P. Folióes e prefeitura disputam carnaval em Belo Horizonte. Carta Capital, 27

\begin{abstract}
Frederico Canuto é graduado em Arquitetura e Urbanismo pela Pontifícia Universidade Católica de Minas Gerais (PUC-Minas); mestre em Arquitetura pela Universidade Federal de Minas Gerais (UFMG); doutor em Poéticas da Modernidade pela UFMG; professor adjunto na Escola de Arquitetura da UFMG. E-mail: fredcanuto@gmail. com

Artigo recebido em 8 de maio de 2016 e aprovado para publicação em 21 de setembro de 2016.
\end{abstract}


fev. 2015. Disponível em: <http://www.cartacapital.com.br/sociedade/folioes-e-prefeitura-disputam-pelo-carnaval-em-belo-horizonte-7733.html>. Acesso em: 5 maio 2016.

CLASTRES, P. Guerra nas sociedades ameríndias. In: . Arqueologia da violência. São Paulo: Cosac Naify, 2011. p. 215-250.

Sociedade contra o Estado. São Paulo: Cosac Naify, 2013.

CONHEÇA as rainhas e madrinhas de bateria famosas do Carnaval do Rio de Janeiro. Abril.com, São Paulo, n.d. Disponível em: <http://www.abril.com.br/entretenimento/ fotos/conheca-rainhas-madrinhas-bateria-famosas-carnaval-rio-janeiro-abril-525388. shtml>. Acesso em: 6 maio 2016.

CRUZ, L et al. Imóvel é cedido a integrantes da ocupação Luiz Estrela. Estado de Minas, 18 dez. 2013. Disponível em: <http://www.em.com.br/app/noticia/gerais/2013/12/18/interna_ gerais,480552/imovel-e-cedido-a-integrantes-da-ocupacao-espaco-luiz-estrela.shtml>. Acesso em: 6 ago. 2016.

DEBORD, G. Sociedade do espetáculo. Comentários sobre a sociedade do espetáculo. Rio de Janeiro: Contraponto, 1997.

Questôes sobre a construção de situações. In: JACQUES, P. B. Apologia da Deriva. Rio de Janeiro: Casa da Palavra, 2003. p. 62-64.

DELEUZE, G.; GUATTARI, F. Mil platôs. Capitalismo e esquizofrenia. Lisboa: Assírio Alvim, 2002.

DIAS, P. L. C. The appropriation of streets in Belo Horizonte by contemporary carnival blocks. Revista Brasileira de Estudos Urbanos e Regionais, v. 17, n. 3, p. 86-103, set./dez. 2015. http://dx.doi.org/10.22296/2317-1529.2015v17n3p86

EHRENREICH, B. Dançando nas ruas. Uma história do êxtase coletivo. Rio de Janeiro: Record, 2010.

FOLIA do bloco "Tchanzinho Zona Norte" também termina em tumulto com a PM. Portal $R 7,6$ fev. 2016. Disponível em: <http://noticias.r7.com/minas-gerais/folia-do-blocotchanzinho-zona-norte-tambem-termina-em-tumulto-com-a-pm-06022016>. Acesso em: 2 maio 2016.

FOUCAULT, M. Em defesa da sociedade. São Paulo: Martins Fontes, 2005. Segurança, território e população. São Paulo: Martins Fontes, 2008a. . O nascimento da biopolítica. São Paulo: Martins fontes, $2008 \mathrm{~b}$.

GOMES, R. Os rolezinhos e a bolha democrática. Blog Das Lutas, 21 jan. 2014. Disponível em: <https://daslutas.wordpress.com/2014/01/21/os-rolezinhos-e-a-bolha-democratica/>. Acesso em: 4 maio 2016.

GUARINELlO, N. L. Festa, Trabalho e Cotidiano. In: JANCSÓ, I.; KANTOR, I. (Org.). Festa: cultura e sociabilidade na América Portuguesa. São Paulo: Hucitec, FAPESP, 2001. s/p

GUIMARAES, S. P. Com mais mortes que Iraque, Brasil está em guerra e não sabe. Exame, 18 jul. 2013. Disponível em: <http://exame.abril.com.br/brasil/noticias/nem-iraquenem-sudao-brasil-esta-em-guerra-e-nao-sabe>. Acesso em: 4 maio 2016.

HAESBERT, R. Viver no Limite: território e multi/transterritorialidade em tempos de in-segurança e contenção. Rio de Janeiro: Bertrand Brasil, 2014.

LAFLOUFA, J. Skol volta atrás e troca peças de campanha de Carnaval por opçôes que incentivam o respeito. Portal B9, 13 fev. 2015. Disponível em: <http://www.b9.com.br/55260/advertising/skol-volta-atras-e-troca-pecas-decampanha-de-carnaval-por-opcoes-que-incentivam-o-respeito/>. Acesso em: 4 maio 2016.

LEFEBVRE, H. The Survival of Capitalism. New York: St Martin Press, 1976. . A Revolução Urbana. Belo Horioznte: Ed. UFMG, 2000.

. Critique of everyday life. Foundations for a Sociology of the Everyday. v. 2. London: Verso, 2008. 
LOBATO, P. H. Praça ABC vira palco de Guerra. Estado de Minas, 9 fev. 2016a. Disponível em: <http://www.em.com.br/app/noticia/gerais/2016/02/09/interna_ gerais,732704/praca-abc-vira-campo-de-guerra-policia-diz-que-confusao-comecoudepoi.shtml>. Acesso em: 2 maio 2016.

. BH poderá ter ônibus gratuitos aos domingos e feriados. Estado de Minas, 24 jul. $2016 \mathrm{~b}$. Disponível em: <http://www.em.com.br/app/noticia/gerais/2016/07/24/interna_ gerais,786915/bh-podera-ter-onibus-gratuitos-aos-domingos-e-feriados.shtml>. Acesso em: 2 ago. 2016.

MACHADO, F. Blocos de rua de $\mathrm{BH}$ divulgam manifesto de repúdio contra a Skol. Estado de Minas, 16 fev. 2015. Disponível em: <http://divirta-se.uai.com.br/app/noticia/especiais/carnaval/2015/02/24/noticia_carnaval,165002/blocos-de-rua-de-bh-divulgam-manifesto-de-repudio-contra-a-skol.shtml>. Acesso em: 4 maio 2016.

MANIFESTAÇÃO LGBT em BH. Estado de Minas, 1 mar. 2013. Disponível em: <http://www.em.com.br/app/galeria-de-fotos/2013/03/01/interna_ galeriafotos,3376/manifestacao-lgbt-em-bh.shtml>. Acesso em: 4 maio 2016.

MENDES, H. De 'escolta VIP' a cinema, camarotes ofertam mordomias no Carnaval 2016. Portal Globo G1, 15 jan. 2016. Disponível em: <http://g1.globo.com/bahia/carnaval/2016/noticia/2016/01/de-escolta-vip-cinemacamarotes-ofertam-mordomias-no-carnaval-2016.html>. Acesso em: 5 maio 2016.

MIRANDA, B. Coletivo Muitxs quer entrar para a política formal em BH. O Tempo, 16 maio 2016. Disponível em: <http://www.otempo.com.br/cidades/coletivo-muitxsquer-entrar-para-a-pol\%C3\%ADtica-formal-em-bh-1.1300292>. Acesso em: 6 ago. 2016.

MOLIARI, C. Anota reforça a malhação para desfilar. 'Medo da perna balançar'. Portal Pure People, 4 jan. 2016. Disponível em: <http://www.purepeople.com.br/noticia/carnaval2016-anitta-reforca-malhacao-para-desfilar-medo-da-perna-balancar_a93561/1>. Acesso em: 5 maio 2016.

MOUFFE, C. The Democratic Paradox. New York: Verso, 2000. .; ERREJON, I. Construir Pueblos, Madrid: Icaria, 2015.

OLIVEIRA, N.; KIFER, C. Sexta-feira tem protesto de ciclistas nas ruas de Belo Horizonte. O Tempo, 31 jan. 2014. Disponível em: <http://www.otempo.com.br/cidades/sextafeira-tem-protesto-de-ciclistas-nas-ruas-de-belo-horizonte-1.782271>. Acesso em: 6 ago. 2016.

PACELLI, S. Blocos de carnaval divulgam nota de repúdio à "camarotização" e à PBH. Estado de Minas, 24 nov. 2015. Disponível em: <http://divirtase.uai.com.br/app/noticia/musica/2015/11/24/noticia_musica,174456/blocos-decarnaval-divulgam-nota-de-repudio-a-camarotizacao-e-a-pbh.shtml>. Acesso em: 5 maio. 2016.

PIMENTEL, T. Praça de BH sedia $1^{\circ}$ Campeonato Interdrag de 'Gaymada' da capital. Portal Globo G1, 13 jun. 2015. Disponível em: <http://g1.globo.com/minasgerais/noticia/2015/06/praca-de-bh-sedia-1-campeonato-interdrag-de-gaymada-dacapital.html>. Acesso em: 4 maio 2016.

. Ciclistas de BH tiram a roupa para pedir mais segurança no trânsito. Portal Globo G1.6 mar. 2016. Disponível em:<http://g1.globo.com/minas-gerais/noticia/2016/03/ciclistasde-bh-tiram-roupa-para-pedir-mais-seguranca-no-transito.html>. Acesso em: 6 ago. 2016.

PREFEITURA DE BELO HORIZONTE. Panorama de açôes do Município de Belo Horizonte voltadas à população de LGBT. Belo Horizonte: Prefeitura de Belo Horizonte, 2015. Disponível em: <http://gestaocompartilhada.pbh.gov.br/sites/gestaocompar- 
tilhada.pbh.gov.br/files/biblioteca/arquivos/relatorio_lgbt_no_municipio_de_belo_ horizonte_-_2015.pdf>. Acesso em: 2 ago. 2016.

PREFEITURA lança programa BH sem Homofobia e avança no combate à discriminaçấo. Portal Prefeitura de Belo Horizonte, 29 jan. 2015. Disponível em: $<$ http://portalpbh.pbh.gov.br/pbh/ecp/noticia.do?evento=portlet\&pAc=not\&idConteudo $=187585 \&$ pIdPlc $=\&$ app $=$ salanoticias $>$. Acesso em: 2 ago. 2016.

RICCI, R.; ARLEY, P. Nas Ruas. A outra política que emergiu em Junho de 2013. Belo Horizonte: Letramento, 2014.

ROUVENAT, F. Saiba quanto custa e como comprar fantasias para o desfile do Rio. Portal Globo G1, 26 jan. 2016. Disponível em: <http://g1.globo.com/rio-dejaneiro/carnaval/2016/noticia/2016/01/saiba-quanto-custa-e-como-comprar-fantasias -para-o-desfile-do-rio.html>. Acesso em: 2 maio 2016.

SILVA, C. Tarifa Zero critica ônibus patrocinado no carnaval de BH. Estado de Minas, 22 jan. 2016. Disponível em: <http://www.em.com.br/app/noticia/gerais/2016/01/22/interna_ gerais, $727520 /$ tarifa-zero-critica-onibus-gratuito-patrocinado-no-carnaval-de-bh. shtml>. Acesso em: 4 maio 2016.

SILVA, E. O. O Movimento rolezinho. Portal JusBrasil, 2014[?]. Disponível em: <http://evanderoliveira.jusbrasil.com.br/artigos/152053538/o-movimento-rolezinho>. Acesso em: 2 maio 2016.

SILVA, R. H. A. Ruas e Redes: dinâmicas dos Protestos BR. Belo Horizonte: Autêntica, 2014. SOUZA, J. A tolice da inteligência brasileira. São Paulo: LeYa, 2015.

SOUZA, M. L. Mudar a Cidade: introdução a um planejamento e gestáo críticos. Rio de Janeiro: Bertrand Brasil, 2002. A Prisão e a Ágora. Rio de Janeiro: Bertrand Brasil, 2006

. Dos espaços de controle aos territórios dissidentes: escritos de divulgação científica e análise política. Rio de Janeiro: Consequência, 2016.

; RODRIGUES, G. B. Planejamento urbano e ativismos sociais. São Paulo: Ed. UNESP, 2004. 